\title{
Effect of Some Micronutrients on Growth and Yield of Wheat and its Leaves and Grain Content of Iron and Boron
}

\author{
Hamzeh RAWASHDEH ${ }^{1,2^{*}}$ Florin SALA ${ }^{2}$ \\ ${ }^{1}$ Water Management and Environment Research Department, National Center for Agricultural \\ Research and Extension, P.O. Box 639, Baqa 19381, Jordan \\ ${ }^{2}$ Soil Sciences and Plant Nutrition, Banat's University of Agricultural Sciences and Veterinary Medicine, \\ “King Michael I of Romania”, Aradului Street, 119, 300645, Romania \\ *Corresponding author: hamz_rawashdeh@yahoo.com
}

Bulletin USAMV series Agriculture 72(2)/2015

Print ISSN 1843-5246; Electronic ISSN 1843-5386

DOI 10.15835/buasvmcn-agr: 11334

\begin{abstract}
Field studies were carried out during the growing season 2012-13 and 2013-14 at Banat's university of agricultural sciences and veterinary medicine, Timisoara, Romania to study the effect of foliar $\mathrm{Fe}, \mathrm{B}$ and $\mathrm{Fe}+\mathrm{B}$ fertilizer at two growth stages on growth, yield and nutrient concentration in flag leaves and grains of wheat. The treatments were laid out in randomized complete block design (RCBD) with three replications. Two years average results show that treatment receiving $333 \mathrm{~g} \mathrm{Fe} \mathrm{ha}^{-1}+167 \mathrm{~g} \mathrm{~B} \mathrm{ha}^{-1}$ at both growth stages ZGS21+ZGS41 produced the highest plant height $(86.0 \mathrm{~cm})$, flag leaf area $\left(28.66 \mathrm{~cm}^{2}\right)$, chlorophyll content (58.0 SPAD value) and grain yield (518 $\mathrm{gm} \mathrm{m}^{-2}$ ). All micronutrients ( $\mathrm{Fe}, \mathrm{B}$ and $\mathrm{Fe}+\mathrm{B}$ ) sprayed at both stages (ZGS21+ZGS41) significantly improved micronutrients concentration in wheat flag leaf and grains over control treatment.
\end{abstract}

Keywords: iron, boron, foliar fertilization, wheat.

\section{INTRODUCTION}

In Romania, wheat (Ttriticum aestivum L.) is grown on an area of 2.135 million hectares with the total production 7.428 million tones, in average yield of 3.479 tons ha $^{-1}$. In 2013, considering the area cultivated with wheat crop, Romania taken the $4^{\text {th }}$ place after France, Germany and Poland and, occupying into amount the yield, the $6^{\text {th }}$ place following France, Germany, United Kingdom, Poland and Spain (Sala et al., 2015). Considering the production of wheat, Romania is between the last countries between the Member States (INS, 2014).

Fertilizers are necessary for enhancing productivity in crops especially in wheat, rising use macronutrients and low use micronutrients leading to an imbalance of soil chemical. A staple fertilization program with macronutrients and micronutrients in plant nutrition is very essential in the high production of yield with good quality products, so there is a need balance use of fertilizers and agronomic procedures are needed to increase yield of this crop. The function of macronutrients and micronutrients is vital in crop nutrition for improved yield and quality (Saeed et. al, 2012).

Micronutrients such as $\mathrm{Fe}$ and $\mathrm{B}$ have essential roles in plant's life cycle and very essential for normal growth plants (Mengel et al., 2001; Fageria, 2007). Iron is most important for the respiration and photosynthesis processes. Iron is play responsibility in many plant functions. These functions include chlorophyll development, energy transfer, a ingredient of sure enzymes and proteins, and involved in nitrogen fixation. It plays an essential role in nucleic acid metabolism (Pervaiz et al., 2003; Eskandari, 2011; Sala, 2011; Havlin et al., 2014). Boron is a micronutrient 
required for all plant nutrition. Boron involves at least 16 functions in plants. These functions include cell wall formation, membrane integrity, cell wall syntheses, carbohydrate metabolism, calcium uptake, flowering, RNA metabolism, respiration, indole acetic acid, (IAA) metabolism, membranes, root growth, pollination and may help in the translocation of sugar (Parr and Loughman, 1983; Bonilla et.al., 2009; Sala 2011; Pandey et al., 2013).

Foliar fertilization (or foliar feeding) is a moderately new and contentious technique of feeding plants by applying liquid fertilizer directly to their leaves (Nasiri et al., 2010).

Current research has discovered that small quantities of micronutrients, especially $\mathrm{Fe}$ and $\mathrm{B}$ either solitary or association with other micronutrients, applied by foliar spraying significantly enhanced growth and increased yield, yield components and grain quality of wheat crop. Ziaeian and Malakouti (2001) found that $\mathrm{Fe}, \mathrm{Mn}, \mathrm{Zn}$ and $\mathrm{Cu}$ fertilization significantly increased grain yield, straw yield, 1000-grain weight, and the number of grains per spikelet. Also showed that application of Fe significantly increased the concentration and total uptake of Fe in grain, flag leaves grain protein contents as well. Asad and Rafique (2002) found that application micronutrients increased wheat dry matter, grain yield, and straw yield significantly over an unfertilized control. Foliar application of micronutrients ( $\mathrm{Fe}, \mathrm{Mn}, \mathrm{Zn}, \mathrm{Cu}$ and $\mathrm{B}$ ) at different growth stages of wheat increased plants height, grains per spike, 1000-grain weight, biological yield, harvest index, straw and grain yield (Khan et al., 2010). Ali (2012) reported that foliar application of $\mathrm{Fe}$ at different growth stages enhanced plant height, spike length, 1000-grain weight, grain weight per spike, grain yield, grain protein content and protein yield of wheat plant in both growing seasons as compared to control. Rawashdeh and Sala (2013) reported that foliar application of $\mathrm{Fe}$ and $\mathrm{B}$ significantly increased plant height, number of tillers and root depth as compared to control treatment (no Fe and B application). Gomaa et al. (2015) found that the foliar application of mixture nutrients $(\mathrm{Zn}+\mathrm{Fe})$ gave the highest grain and yield components and quality of wheat grain. Foliar application of $\mathrm{B}$ and $\mathrm{Zn}$ had positive effect on yield and yield components of wheat (Ali et al., 2009; Moghadam et al., 2012). Raza et al. (2014) reported that foliar application of B was significant affected on grain yield, number of grains per spike and 1000-grain weight.

The objectives of the experiment were to study the effect of foliar application of some micronutrients $(\mathrm{Fe}, \mathrm{B}, \mathrm{Fe}+\mathrm{B})$ at two growth stages on growth, yield quantity and quality also to increased concentration of Fe in grain of wheat.

\section{MATERIALS AND METHODS}

Two field experiments were conducted at the Didactic Station, Banat's University of Agricultural Sciences and Veterinary Medicine, Timisoara, Romania during growing seasons 2012-13 and 2013-14. Texturally the soil was clay. It contained $6.86 \mathrm{pH}, 0.50 \mathrm{EC}, 3.35 \%$ Humus, $0.19 \%$ total N, $12.91 \mu \mathrm{g} \mathrm{g}^{-1}$ available $\mathrm{P}, 169.37 \mu \mathrm{g} \mathrm{g}^{-1}$ available $\mathrm{K}, 1.12 \mu \mathrm{g} \mathrm{g}^{-1}$ available $\mathrm{Zn}, 3.32 \mu \mathrm{g} \mathrm{g}^{-1}$ available Fe and $0.26 \mu \mathrm{g} \mathrm{g}^{-1}$ available B contents. The crop cultivar was Alex. The experiment was arranged in a randomized complete block design with three replications, each plot being $10.0 \mathrm{~m}$ long x $3.0 \mathrm{~m}$ wide.

Treatments including: T1: control; distilled water spray, T2: $333 \mathrm{~g} \mathrm{Fe} \mathrm{ha}^{-1}$ at ZGS21, T3: $333 \mathrm{~g}$ Fe ha ${ }^{-1}$ at ZGS41, T4: $333 \mathrm{~g} \mathrm{Fe} \mathrm{ha}^{-1}$ at ZGS21+ZGS41, T5: $167 \mathrm{~g} \mathrm{~B} \mathrm{ha}^{-1}$ at ZGS21, T6: $167 \mathrm{~g} \mathrm{~B} \mathrm{ha}^{-1}$ at ZGS41, T7: $167 \mathrm{~g} \mathrm{~B} \mathrm{ha}^{-1}$ at ZGS21+ZGS41, T8: 333g Fe ha${ }^{1}+167 \mathrm{~g} \mathrm{~B} \mathrm{ha}^{-1}$ at ZGS21, T9: $333 \mathrm{~g} \mathrm{Fe} \mathrm{ha}^{-1}+167 \mathrm{~g} \mathrm{~B}^{-1}$ ha $^{-1}$ at ZGS41, T10: 333g Fe ha-167g B ha-1 at ZGS21+ZGS41.

Foliar solutions were sprayed with a hand held spray bottle at the rate of $400 \mathrm{~L} \mathrm{ha}^{-1}$ on plant foliage according to the Zadok's scale as described by (Zadoks et al., 1974). Nitrogen was applied in two doses. First dose of $\mathrm{N}$ was applied at 4 weeks after sowing in the form of complex 15:10:10 $\mathrm{N}: \mathrm{P}: \mathrm{K}$, respectively and at a rate of $360 \mathrm{~kg} \mathrm{ha}^{-1}$. Second dose of $\mathrm{N}$ was applied in the form of urea at the stem elongation stage at a rate of $100 \mathrm{~kg} \mathrm{ha}^{-}$ 1. Besides micronutrients ( $\mathrm{Fe}, \mathrm{B}$ and $\mathrm{Fe}+\mathrm{B}$ ), every treatment had received the same dose of NPK fertilizer.

Data on the growth and yield were recorded. Grain and flag leaf samples from every plot were analyzed for $\mathrm{Fe}, \mathrm{B}, \mathrm{Zn}$, and $\mathrm{Cu}$ contents. All data were statistically analyzed using MSTAT-C statistical computer package software version 2.10 for a randomized complete block design (Michigan State University, 1991). Mean comparisons of the 
treatments were made by the Least Significant Difference (LSD) test at 0.05 level of probability $(p=0.05)$ comparison method (MSTAT-C, 1991).

\section{RESULTS AND DISCUSSION Plant height}

Two years average, data in (Figure 1) showed that the plant height increased significantly $(p=0.05)$ due to foliar application of micronutrient $(\mathrm{Fe}, \mathrm{B}, \mathrm{Fe}+\mathrm{B})$ at individual stages (ZGS21 or ZGS41) and at both stages (ZGS21+ZGS41). The highest height plant mean value was obtained in T10 followed by T4 and T8. These treatments (T10, T8 and T4) showed 14.00\%, 12.33\% and $11.20 \%$ increase in plant height over control (T1), respectively. The lowest height plant mean value was achieved from control treatment (T1).

Iron has a structural role in chlorophyll, energy transfer within the plant and enters in root cells and B plays an important role in the physiological process of plants, such as, cell elongation, cell maturation, meristematic tissue development, sugar transportation, IAA, formation, germination and protein synthesis. This in turn, maybe leads to an increase in plant height of wheat. This result is agreement with (Ali, 2012; Bameri et al, 2012; Rehman et al, 2012; Rawashdeh and Sala, 2013) who reported plant height increased due to micronutrient foliar application.

\section{Flag leaf area}

The mean data of the two years (2012-2014) showed that flag leaf area increased significantly

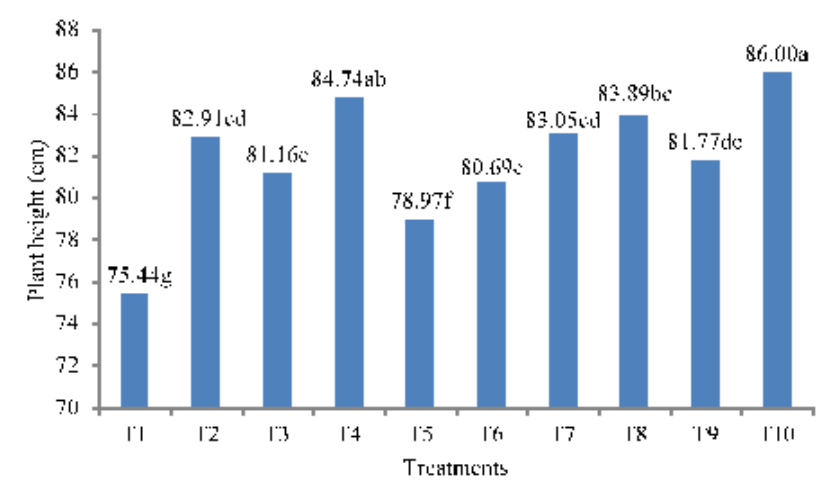

Fig. 1. Plant height as affected by application of micronutrients ( $\mathrm{Fe}, \mathrm{B}$ and $\mathrm{Fe}+\mathrm{B}$ ) at different growth stages (Mean of two years); Column means followed by the same letter(s) are not significantly different at $5 \%$ probability using LSD test. $(p=0.05)$ by employed foliar application of micronutrient $(\mathrm{Fe}, \mathrm{B}$ and $\mathrm{Fe}+\mathrm{B})$ at individual growth stages (ZGS21 or ZGS41) and at both stages of growth (ZGS21+ZGS41). According to (Figure 2) the greatest flag leaf area mean value was obtained in (T10) followed by T4, T7 and T9. These treatments (T10, T4, T7 and T9) showed $39.13 \%, 27.57 \%, 22.43 \%$ and $19.13 \%$ increase in flag leaf area over control (T1) respectively, while the smallest flag leaf area mean value was recorded in control treatment.

Fe is an important nutrient in crops because it is necessary for many important enzymes, as well as cytochrome that is involved in electron transport chain, synthesize chlorophyll, keeps up the structure of chloroplasts, involved in nitrogen fixation and increases enzymes activities (Eskandari, 2011) which lead to higher crop production and leaf area increase (Zayed et al., 2011). Boron application at different growth stages improves the flag leaf area. Accessibility of enough nutrients resulted in higher leaf area, which in turn improved the photosynthetic activity and in the end higher dry matter accumulation. These results are supported by (Nadim et al., 2012) who observed significantly higher leaf area index by the application different micronutrients to wheat.

In general, the application of $\mathrm{Fe}$ and $\mathrm{B}$ had increased the tissue formation with better plant growth which increases its concentration in leaves and results in higher leaf area.

\section{Chlorophyll content}

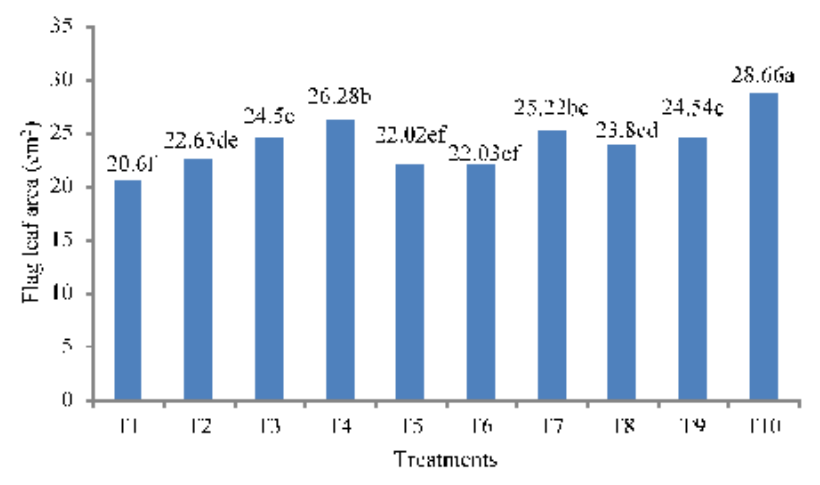

Fig. 2. Flag leaf area as affected by application of micronutrients $(\mathrm{Fe}, \mathrm{B}$ and $\mathrm{Fe}+\mathrm{B})$ at different growth stages (Mean of two years); Column means followed by the same letter(s) are not significantly different at 5\% probability using LSD test. 
Average data of two years (2012-2014) showed that flag leaf chlorophyll content increased significantly $(p=0.05)$ due to foliar application of micronutrient $(\mathrm{Fe}, \mathrm{B}$ and $\mathrm{Fe}+\mathrm{B})$ at individual growth stages (ZGS21 or ZGS41) and at both stages of growth (ZGS21+ZGS41). The greatest flag leaf chlorophyll content mean amount was obtained in (T10) Followed by T4, T3 and T9. These treatments (T10, T4, T3, and T9) showed $18.96 \%$, $16.22 \%, 12.40 \%$ and $12.07 \%$ increase in flag leaf chlorophyll content over control (T1) respectively, while the smallest flag leaf chlorophyll content mean value was recorded in control treatment (Figure 3). It shows that Fe was more effectual on the chlorophyll content than B. These results might be due to the critical role of Fe nutrient in crop growth, involving in chlorophyll formation, photosynthesis, chloroplast development and respiration of plants and other biochemical and physiological activates (Zeidan et al., 2010). These results were agreement with (Kazemi, 2013; Rawashdeh and Sala, 2014 a,b) who demonstrated that adding $\mathrm{Fe}$ and $\mathrm{B}$ alone or in association with other micronutrients increased chlorophyll content of plants.

\section{Grain yield}

Mean of two years (2012-2014) data showed that grain yield increased significantly at 5\% probabilitylevel $(p=0.05)$ dueto foliarapplication of micronutrient $(\mathrm{Fe}, \mathrm{B}$ and $\mathrm{Fe}+\mathrm{B})$ at different growth stages. Figure (4) showed that the greatest grain

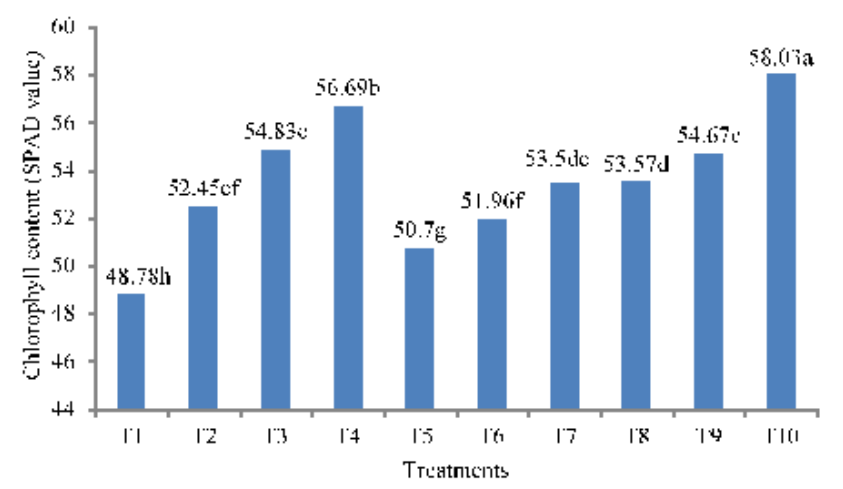

Fig. 3. Chlorophyll content as affected by application of micronutrients $(\mathrm{Fe}, \mathrm{B}$ and $\mathrm{Fe}+\mathrm{B})$ at different growth stages (Mean of two years); Column means followed by the same letter(s) are not significantly different at $5 \%$ probability using LSD test. yield mean amount (518 $\mathrm{mg} \mathrm{m}^{-2}$ ) was obtained in (T10) when plants received micronutrient $(\mathrm{Fe}+\mathrm{B})$ at both growth stages (ZGS21+ZGS41) followed by T7 (498.8 $\mathrm{mg} \mathrm{m}^{-2}$ ), T6 (478 $\mathrm{gm} \mathrm{m}^{-2}$ ) and T9 (475.7 $\mathrm{gm} \mathrm{m}^{-2}$ ) due to $\mathrm{B}$ application single at both growth stages (ZGS21+ZGS41), B application single at individual growth stage (ZGS41) and $\mathrm{Fe}+\mathrm{B}$ application at individual growth stage (ZGS41), respectively. These treatments (T10, T7, T6, and T9) showed $32.55 \%, 27.64 \%, 22.31 \%$ and $21.72 \%$ increase in grain yield over control respectively, while the smallest grain yield mean value (390.8 $\mathrm{gm}^{-2}$ ) was recorded in control treatment (T1). These results are in good line with the findings of (Zada and Afzal, 1997; Ali, 2012; Tahir et al., 2009; Khan et al., 2010; Nadim et al 2012; Raza et al., 2014), reported that the grain yield of wheat increased due to the application of $\mathrm{Fe}$ and $\mathrm{B}$ solitary or association with other micronutrients. This may be due to better crop nutrition through foliar application of $\mathrm{Fe}$ and $\mathrm{B}$ at individual growth stages and at both stages of growth also due to most important roles of Fe and B in plant growth and development which may result in improved crop growth and increased production.

\section{Micronutrients concentration in Flag leaves and Grains}

Mean two years values presented in (Table 1), the results indicated that the highest micronutrients $\mathrm{Fe}, \mathrm{B}, \mathrm{Zn}$, and $\mathrm{Cu} \mu \mathrm{gg}^{-1}$ concentration in flag leaves and grains were recorded when plant

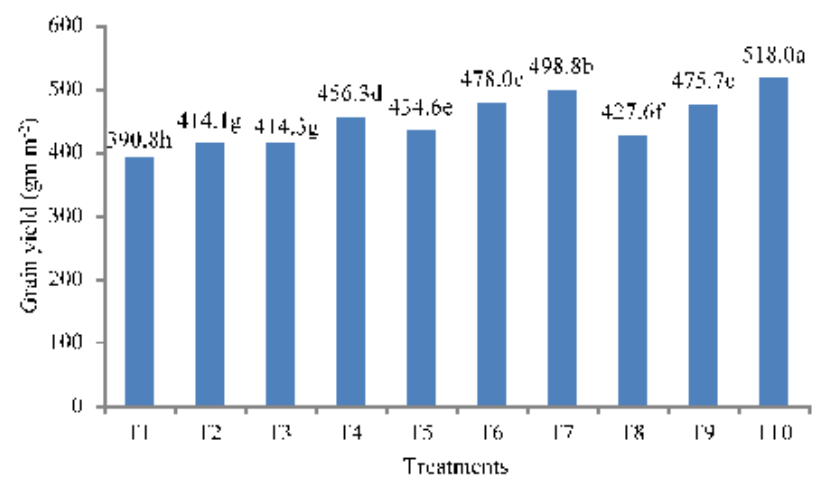

Fig. 4. Grain yield as affected by application of micronutrients ( $\mathrm{Fe}, \mathrm{B}$ and $\mathrm{Fe}+\mathrm{B}$ ) at different growth stages (Mean of two years); Column means followed by the same letter(s) are not significantly different at $5 \%$ probability using LSD test. 
Tab. 1. Micronutrients concentration $\left(\mu \mathrm{g} \mathrm{g}^{-1}\right)$ in Flag leaves and grains of wheat (Mean of two years)

\begin{tabular}{ccccccccc}
\hline \multirow{2}{*}{ Treatments } & \multicolumn{9}{c}{ Flag leaves } & \multicolumn{4}{c}{ Grains } \\
\cline { 2 - 9 } & $\mathrm{Fe}$ & $\mathrm{B}$ & $\mathrm{Zn}$ & $\mathrm{Cu}$ & $\mathrm{Fe}$ & $\mathrm{B}$ & $\mathrm{Zn}$ & $\mathrm{Cu}$ \\
\hline $\mathrm{T} 1$ & $45.34 \mathrm{~F}$ & $0.27 \mathrm{C}$ & $12.89 \mathrm{~F}$ & $1.67 \mathrm{H}$ & $42.94 \mathrm{G}$ & $0.67 \mathrm{H}$ & $20.03 \mathrm{G}$ & $4.44 \mathrm{I}$ \\
\hline $\mathrm{T} 2$ & $58.74 \mathrm{D}$ & $0.31 \mathrm{C}$ & $15.52 \mathrm{CD}$ & $1.84 \mathrm{G}$ & $47.61 \mathrm{E}$ & $0.83 \mathrm{G}$ & $21.73 \mathrm{E}$ & $4.85 \mathrm{G}$ \\
\hline $\mathrm{T} 3$ & $87.87 \mathrm{~B}$ & $0.30 \mathrm{C}$ & $16.30 \mathrm{C}$ & $2.14 \mathrm{E}$ & $49.56 \mathrm{D}$ & $1.01 \mathrm{~F}$ & $21.54 \mathrm{EF}$ & $5.26 \mathrm{CD}$ \\
\hline $\mathrm{T} 4$ & $94.92 \mathrm{~A}$ & $0.35 \mathrm{C}$ & $18.09 \mathrm{AB}$ & $2.38 \mathrm{~B}$ & $54.74 \mathrm{~B}$ & $1.09 \mathrm{~F}$ & $24.67 \mathrm{~B}$ & $5.41 \mathrm{~B}$ \\
\hline $\mathrm{T} 5$ & $49.22 \mathrm{EF}$ & $0.95 \mathrm{~B}$ & $13.97 \mathrm{EF}$ & $1.76 \mathrm{GH}$ & $44.97 \mathrm{~F}$ & $1.26 \mathrm{E}$ & $20.90 \mathrm{~F}$ & $4.72 \mathrm{H}$ \\
\hline $\mathrm{T} 6$ & $50.23 \mathrm{E}$ & $1.04 \mathrm{~B}$ & $14.09 \mathrm{EF}$ & $2.17 \mathrm{DE}$ & $44.37 \mathrm{FG}$ & $1.45 \mathrm{C}$ & $21.97 \mathrm{E}$ & $5.11 \mathrm{EF}$ \\
\hline $\mathrm{T} 7$ & $53.61 \mathrm{E}$ & $1.63 \mathrm{~A}$ & $14.93 \mathrm{DE}$ & $2.26 \mathrm{C}$ & $46.68 \mathrm{E}$ & $1.64 \mathrm{~B}$ & $23.84 \mathrm{C}$ & $5.19 \mathrm{DE}$ \\
\hline $\mathrm{T} 8$ & $59.10 \mathrm{D}$ & $0.97 \mathrm{~B}$ & $16.84 \mathrm{BC}$ & $2.04 \mathrm{~F}$ & $50.90 \mathrm{CD}$ & $1.34 \mathrm{DE}$ & $24.18 \mathrm{BC}$ & $5.04 \mathrm{~F}$ \\
\hline $\mathrm{T} 9$ & $82.41 \mathrm{C}$ & $1.24 \mathrm{~B}$ & $16.16 \mathrm{CD}$ & $2.23 \mathrm{CD}$ & $52.21 \mathrm{C}$ & $1.40 \mathrm{CD}$ & $23.11 \mathrm{D}$ & $5.30 \mathrm{C}$ \\
\hline $\mathrm{T} 10$ & $98.21 \mathrm{~A}$ & $1.84 \mathrm{~A}$ & $18.42 \mathrm{~A}$ & $2.55 \mathrm{~A}$ & $56.59 \mathrm{~A}$ & $1.76 \mathrm{~A}$ & $26.49 \mathrm{~A}$ & $5.66 \mathrm{~A}$ \\
\hline LSD & 4.39 & 0.3583 & 1.344 & 0.0905 & 1.625 & 0.1045 & 0.7243 & 0.0905 \\
\hline Means followedby same letter are not significantly different at 5\% probability using LSD test. & & &
\end{tabular}

treated with micronutrients $\mathrm{Fe}+\mathrm{B}$ at both growth stages (T10). The lowest of these nutrients were observed in control treatment (T1). These results are agreement with the finding of (Zeidan et al. 2010; Gomaa et al., 2015), who reported that foliar application of micronutrients significantly increased concentration of micronutrients in flag leaves and grains.

\section{CONCLUSION}

Current study showed that the foliar application of $\mathrm{Fe}, \mathrm{B}$ and $\mathrm{Fe}+\mathrm{B}$ at individual growth stages (ZGS21 or ZGS41) and at both growth stages (ZGS21+ZGS41) of wheat significantly increased chlorophyll content, flag leaf area, grain yield and enhanced micronutrients concentration in flag leaves and grains. Treatment (T10) gave the highest values of all studied parameters. Whilst, the lowest values of all studied parameters were obtained from control treatment.

\section{REFERENCES}

1. Ali EA (2012). Effect of Iron Nutrient Care Sprayed on Foliage at Different Physiological Growth Stages on Yield and Quality of Some Durum Wheat (Triticum durum L.) varieties in Sandy Soil. Asian J. of Crop Sci. 4 (4): 139-149.

2. Ali S, Shah A, Arif M, Miraj G, Ali I, Sajjad M, Farhatullah, Khan MY, Khan NM (2009). Enhancement of wheat grain yield and yield components through foliar application of Zinc and Boron. Sarhad J. Agric. 25(1): 15-19.

3. Asad A, Rafique R (2002). Identification of micronutrient deficiency of wheat in the peshawar valley, pakistan. Communications in Soil Science and Plant Analysis, 33(34): 349-364.
4. Bameri M, Abdolshahi R, Mohammadi-Nejad G, Yousefi K, Tabatabaie SM (2012). Effect of different microelement treatment on wheat (Triticum aestivum) growth and yield. Intl. Res. J. Appl. Basic. Sci. 3(1): 219-223.

5. Bonilla I, Blevins D, Bolanos L (2009). Boron Functions in Plants: Looking Beyond the Cell Wall. (Ch. 5) In: Taiz L. and Zeiger E. (eds). Plant Physiology. IOP publishing physics. retrieve from web. http://4e.plantphys.net.

6. Eskandari $\mathrm{H}$ (2011). The importance of iron (Fe) in plant Products and Mechanism of Its uptake by plants. J. Appl. Environ. Biol. Sci. 1(10): 448-452.

7. Fageria NK (2007). Soil fertility and plant nutrition research under field conditions: Basic principles and methodology. Journal of Plant Nutrition, 30(2): 203-223.

8. Gomaa MA, Radwan FI, Kandil EE, El-Zweek SMA (2015). Effect of some macro and micronutrients application methods on productivity and quality of Wheat (Triticum aestivum L.). Middle East J. Agric. Res., 4(1): 1-11.

9. Havlin JL, Tisdale SL, Nelson WL, Beaton JD (2014). Soil Fertility and Nutrient Management: An Introduction to Nutrient Management. $8^{\text {th }}$ Ed. Pearson, Upper Saddle River, New Jersey. United States, 505 p.

10. INS (2014). Crop production for the main crops in 2013. National institute of statistics, No. 75, March 31, 2014. pp.5.

11. Kazemi M (2013). Effect of Foliar Application of Iron and Zinc on Growth and Productivity of Cucumber. Bull. Env. Pharmacol. Life Sci., 2(11): 11-14.

12. Khan MB, Farooq M, Hussain M, Shabir S, Shabir G (2010). Foliar application of micronutrients improves the wheat yield and net economic return. Int. J. Agric. Biol., 12(6): 953-956.

13. Mengel K, Kirkby EA (2001): Principles of Plant Nutrition. $5^{\text {th }}$ Ed. Kluwer Academic Publishers, Dordrecht, Boston, London, $849 \mathrm{p}$. 
14. Michigan State University. (1991). MSTAT-C: A Software program for the design, management, and analysis of agronomic research experiments. Michigan State University, Ann Arbor, MI., USA.

15. Moghadam MJ, Sharifabad HH, Noormohamadi G, Sadeghian Motahar Y, Siadat SA (2012). The Effect of Zinc, Boron and Copper Foliar Application, on Yield and Yield Components in Wheat (Triticum aestivum L.). Ann. Biolo. Res. 3(8): 3875-3884.

16. Nadim MA, Awan IU, Baloch MS, Khan EA, Naveed K, Khan MA (2012). response of wheat (Triticum aestivum L.) to different micronutrients and their application methods. J. Anim. Plant Sci. 22(1): 113-119.

17. Nasiri Y, Zehtab-Salmasi S, Nasrullahzadeh S, Najafi N, Ghassemi-Golezani K (2010). Effects of foliar application of micronutrients (Fe and Zn) on flower yield and essential oil of chamomile (Matricaria chamomilla L.). J. Med. Plant. Res., 4(17): 1733-1737.

18. Pandey N, Gupta B (2013). The impact of foliar boron sprays on reproductive biology and seed quality of black gram. J. Tra. Elem. Medi. Biol. 27(1): 58- 64.

19. Parr AJ, Loughman BC (1983). Boron and membrane function in plants. In: Metals and Micronutrients, Uptake and Utilisation by Plants. Robb D.S., Pierpoint W.S. (Eds.) Academic Press, New York. pp. 87-107.

20. Pervaiz Z, Hussain K, KAZMI SSH, Gill KH, Sheikh AA (2003). Iron requirement of Barani wheat. Int. J. Agri Biol., 5(4): 608-610.

21. Rawashdeh H, Sala F (2014a). Influence of iron foliar fertilization on some growth and physiological parameters of wheat at two growth stages. Scientific Papers. Series A. Agronomy, 57: 306-309.

22. Rawashdeh H, Sala F (2014b). The effect of boron foliar fertilizer on some morphological parameters of wheat at different growth stages. Review on Agriculture and Rural Development, 3(1): 27-32.

23. Rawashdeh H, Sala F (2013). Effect of different levels of boron and iron foliar application on growth parameters of wheat seedlings. African Crop Science Conference Proceedings, 11: 861-864.

24. Rawashdeh HM, Sala F (2013). The effect of foliar application of iron and boron on early growth parameters of wheat (Triticum aestivum L.). Research Journal of Agricultural Science, 45 (1): 21-26.

25. Raza SA, Ali S, Chahill ZS, Iqbal RM (2014). Response of foliar application of boron on wheat (Triticum aestivum L) crop in calcareous soils of Pakistan. Acad. J. Agric. Res. 2(3):106-109.

26. Rehman SU, Hussain N, Tariq M, Hussain M, Nasir M, Ayaz M (2012). Response of wheat to exogenous boron supply at various growth stages. Sarhad J. Agric. 28(3): 411-414.

27. Saeed B, Gul H, Khan AZ, Badshah NL, Parveen L, Khan A (2012). Rates and methods of nitrogen and sulfur application influence and cost benefit analysis of wheat. Journal of Agricultural \& Biological Science, 7(2): 81-85.

28. Sala F (2011). Agrochimie, Ed, Timisoara, Romania, pp:.40-41.

29. Sala F, Rawashdeh H, Boldea M (2015). Differentiated contribution of minerals through soil and foliar fertilization to the winter wheat yield. American Journal of Experimental Agriculture, 6(3): 158-167.

30. Tahir M, Tanveer A, Shah TH, Fiaz N, Wasaya A (2009). Yield Response of Wheat (Triticum aestivum L.) to Boron Application at Different Growth Stages. Pak. J. Life Soc. Sci. 7(1): 39-42.

31. Zada K, Afzal M (1997). Effects of boron and iron on yield and yield components of wheat. In: Boron in Soil and Plants. (Eds. R.W. Bell and B. Rerkasem). Kluwer Academic Publishers, Dordrecht, The Netherlands, pp. 35-37.

32. Zadoks JC, Chang TT, Konzak CF (1974). A decimal code for the growth stages of cereals. Weed Res 14(6): 415-421.

33. Zayed BA, Salem AKM, El Sharkawy HM (2011). Effect of different micronutrient treatments on rice (Oriza sativa L.) growth and yield under saline soil conditions. World J. Agric. Sci., 7(2): 179-184

34. Zeidan MS, Manal F, Hamouda HA (2010). Effect of foliar fertilization of Fe, Mn and Zn on wheat yield and quality in low sandy soils fertility. World J Agric Scie. 6(6): 696-699.

35. Ziaeian AH, Malakouti MJ (2001). Effect of micronutrient application on wheat production in calcareous soils. Prepared for the Second National Conference on Optimum Utilization of Chemical Fertilizers and Pesticide in Agriculture, Karaj, Iran. 